\title{
Jonas Holst
}

\section{Tid og eksistens hos Peter Seeberg}

\section{Såret}

Tiden er om noget det fænomen, hvorigennem den menneskelige eksistens tager sin endelige form. I en læsning af en række af Peter Seebergs tekster vil jeg forsøge at vise, hvorledes tiden på een gang samler og spreder menneskets forhold til sig selv, til hinanden og til det omgivende sted. Romanen Hyrder fra 1970 markerer i min læsning en overgang fra de tidlige til de sene værker i forfatterskabet. I dette værk er menneskene - til forskel fra i de tidlige værker - rykket tættere på hinanden, og de indgår alle i en bredere social kontekst, hvorfor sproget og tiden i langt højere grad er lagt ud imellem menneskene. Vi skal senere se, at i det tidlige forfatterskab er menneskene derimod indspundet $\mathrm{i}$ deres egen tid og bevidsthedens indre, evigt kværnende monologer.

I de to første kapitler af Hyrder møder vi Leo Gray, der er på vej væk fra byen Tauben, hvor han har tilbragt en nat med sin elskerinde, Erna, men kun for senere på morgenen at vende om og køre tilbage imod Tauben, hvor Erna stadig befinder sig. Denne figur, at en fremadgående bevægelse modsvares af en tilbagegående bevægelse imod udgangspunktet, er tilbagevendende i Seebergs forfatterskab. I Bipersonerne fyldes dagene af arbejdernes gentagende bevægelser. De genoptager hver morgen arbejdet uden at komme ud af stedet, hvilket specielt kommer til udtryk i opførelsen af kulissestykket samt Sims Sisyfos-arbejde med at fylde en tønde, der skildres minutiøst over to en halv side. I Fugls føde får Tom følgende karakteristik: »Han havde fart på som altid, når han gik alene. Han måtte frem, tit for blot i samme nu at vende om. ${ }^{1} \mathrm{Og}$ i novellen »Hvile« fra Eftersøgningen udgøres selve grundstrukturen af de gentagende cirkler, som Anna slår, idet hun hver dag vandrer fra sit hjem i byen ud til remisen og tilbage igen.

Når de seeberg'ske eksistenser i en tilbagegående bevægelse - og ofte med død og helvede - søger at gennemtrumfe deres intention og således indhente det tabte, så bevæger de sig i retning af deres egen undergang. Det,

1. Peter Seeberg: Fugls føde, Kbh. 1957, p. .9. (Herefter forkortet Ff.) 
som den flygtende forsøger at undfly, imod dét bliver han kastet tilbage. Leo Gray i Hyrder kører galt, efter at han er vendt om for at køre tilbage imod Erna i Tauben, og hans ulykke efterlader følgende spor på et træ i vejkanten:

"Dagen udfældedes som en hvidere luft. Træerne knagede lidt i kronerne, da det blev dag, og den der havde lænet sit hoved ind mod det store barksår, sansede duften af træets skjulte forår og næsten sommer under træerne. $\ll^{2}$

Leo Gray havde lige inden, han kørte galt, indset sin udvejsløse situation, at han kørte bort fra sin egen lykke, Erna, mod sin egen ulykke, sin kone Viola. I et forsøg på at få herredømmet over sin egen livssituation, slår han hurtigt om, men det novemberkolde sted på den øde vej slår tilbage, og hans egen banede vej imod lykken ender i ulykken. Vi kan se, hvordan Seeberg arbejder med det, som han selv har kaldt, at strøm og modstrøm mødes i hans tekster, og at der herigennem pludseligt sker et omslag. ${ }^{3}$ Hvad der nu viser sig, er altså dette sår på træet, som gennembryder det uigennemsigtige landskab, hvor den menneskelige trafik blot forløber, uden at man ænser hinandens skæbner. Et sår har jo det ved sig, at det på een gang åbenbarer menneskets endelighed og samtidig livets pulserende rytme. I såret forbløder livet, men samtidig kommer de kræfter til syne, der bærer og fremkalder livets bevægelse. Og indenfor en seeberg'sk horisont lever mennesket først virkeligt, idet det møder modstand eller udsættes for tilintetgørelse. Dette eksistenssyn hører til i en yderst interessant virkningshistorie, som ikke udspringer af det 20. århundredes eksistensfilosofi, men som skriver sig helt tilbage til den græske tragediedigter Aischylos' credo: pathei mathos - at lære igennem lidelse. Ikke i betydningen, at man bliver klog af skade, men sådan at forstå, at dét at gøre erfaringer er overhovedet at erfare sine egne grænser, sin egen endelighed. ${ }^{4}$ Idet vi vender os imod Hyrder igen, så vil livskraften måske vise sig i det øjeblik, såret heler og stopper blødningen, det tørre inddæmmer det våde element, det varme lægger sig om det kolde og klamme.

Såret står vidt åbent på det træ, som Leo stødte imod, da han kørte galt, og Leos bror, Ole, besegler senere i Hyrder Leos skæbne: „Han kunne være blevet det [noget særligt, min tilføjelse - JH], sagde Ole, men pludselig skiftede han kurs. Det var som om een havde skåret barken af ham.« (H, p.119)

2. Peter Seeberg: Hyrder, Kbh. 1975 (org. 1970), p.28. (Herefter forkortet $H$.)

3. "Tänk att få skriva de nya argumenten«. Interview af Eric Åkerlund i Bonniers Litteræra Magasin nr. 1, 1980.

4. For en uddybning af dette erfaringsbegreb, se Hans-Georg Gadamers Wahrheit und Methode, Tübingen 1990 (org. 1960), pp.352-368. 
Metaforisk knyttes Leos flåede skind her til barksåret, der åbenbarer den tid, som mennesket lever i og med, nemlig årstiderne.

Hvis vi forfølger den krydsrefererende form, der fungerer som en indre dynamik i Hyrder et stykke videre, så er Leos skæbne blevet foregrebet i solsymbolikken, der umiddelbart føjer sig til den skjulte sommerlighed. Solen har kun været fremme i en halv time i hele februar måned »som et skudsår på himlen« $(H$, p.9), hvorefter den var "forsvundet ind i sin egen sky« $(H$, p.10). Her har den skjult sig, og er nærmest blevet kvalt. Første gang, der knyttes en forbindelse imellem Leo og solen, er i Leos karakteristik af sig selv: Han havde altid ønsket at opretholde status quo og havde indset, at det bedst lod sig gøre ved at lukke sig omkring sig selv. Derfor er han lykkeligt ulykkelig, da han kører tilbage imod Erna, fordi lykken over det, der venter ham, underløbes af mismodet over nu ikke længere kun at skulle tænke på sig selv. Lykketilstanden er en risikabel tilstand at befinde sig i, fordi den med sine store udsving forårsager skader, så snart den er forbi: „Men det var ingen varig tilstand, lykken nager sår, som skal heles i skjul og skygge.» $(H$, p.7) Leo er repræsentant for en form for lukket økonomi, der trækker sig tilbage og skjuler sig for at være sig selv nok. Solen og Leo er begge lukket inde i deres egne livssfærer, men ligesom solen viste sig i et skudsår, peger teksten på, at Leo får chancen for et gennembrud i sporet fra barksåret. Sårets anderledes, sommerlige farver gennemtrænger de grå februartåger, og redder ham, da en stedkendt ser træets åreladning. Senere, mens Leo stadig er i coma, sammenligner en sygeplejerske ham med Apollon, solguden i græsk mytologi, efter at hun har set hans ansigt, hvor der var et svagt lys i øjnene. Dette lys og den sommerlighed, der gemmer sig under Leos sollignende ydre, slipper imidlertid ikke Leo fri af hans vinterskcebne. Såret vil ikke hele, og ligesom solen kvæles, tager Leo sin sidste indånding, da han året efter sin ulykke drukner sig.

\section{Dødens element}

Det er et ofte anvendt billede, at døden findes på den anden side af livet, og at det er døden der river mennesket ud af livet; men så vidt jeg kan se, viser der sig noget andet i Seebergs værk: Døden er på den ene side et immanent fænomen i livet. Det enkelte menneskes liv når sin afslutning, idet det forstener, forbløder eller udtørrer. På den anden side er døden bagsiden af dette fænomen, et uoplyseligt mørke, som mennesket intet forhold har til, andet end som præcis en intethedserfaring. Døden manifesterer sig så at sige på kanten af livet, åbenbarende sig i en tilbagetogsbevægelse, som mennesket står i en ikke-relaterende relation til. Sproget slår knuder på sig selv i 
forsøget på at overskride sin begrænsning og komme til at kaste lys over døden. Den fabelagtige livshistorie »Dinosaurusens sene eftermiddag« siger det ganske kort: "I floden voksede intet. I floden druknede man. Floden var ingenting. Den var ikke med i sproget. Der holdt sproget op. Ingenting var for meget at sige. $\|^{5}$ Den paradoksale struktur gentager sig her, hvor floden er grobund for vækst, der intet udfolder. Dinosaurusens tørst bevæger den i retning af floden, og idet dinosaurusen rækker ud efter vandet, der kan redde den, går den i samme bevægelse under, og dens livstørst slukkes endeligt. Leo Gray gik ligeledes under i vandets element, i dammen, der »er både lys og mørk, man kan næsten vende dens flade og få den mørk og lys. Den spejler træerne og en enkelt sky, der driver langsomt hen over parken, og den bliver dyb som himlen« $(H$, p.142). Vandet er det livgivende element, der på overfladen spejler lyset, men som rummer en dybde, mennesket ikke kan nå til bunds i. Lys og mørke, flade og dybde udveklser frit og skifter plads i dammen; dog er det ikke i dette lysende, overfladiske mørkedyb, at døden viser sit ansigt. Ikke i udvekslingen, men i selve den overskridelse, der ikke viser nogen vej tilbage, fremtræder den side ved elementet, der bestandigt unddrager sig oplysningen, og som sætter en grænse, et endeligt punktum for mennesket. Det er mødet med dette bundløse dyb, dødens spor, der står malet i ansigtet på den druknede:

"Leo Gray stiger op fra bunden og flyder midt i dammen, driver måske lidt ind mod bredden, da Rosa kaster sig ud i dammen og står og kæmper med ham og vender ham om. Han har store, vidtopspærrede øjne og hans mund er åben, som havde han råbt« (H, pp.143-144).

Vandet er et sådant 'omgribende' element, som mennesket, idet det befinder sig midt i det, ikke kan komme ud på den anden side af. Elementet er i sit væsen tvetydigt, idet det både bærer mennesket, og lader det synke igennem. I »Vingeslag« fra Argumenter for benådning afprøver den otteårige Charles verdens grænser ved konkret at se, hvad der kan gå i stykker, og hvad der holder. Præcis de fænomener, der ligger udenfor det menneskelige herredømme, viser sig holdbare: elementerne og årets tid. Endnu en gang fremviser Seebergs tekster en indre forbindelse imellem disse to fænomener, der deler det fællestræk, at de er alt og intet, livet og døden, udspring og tilintetgørelse. Denne tvetydighed fremstår til sidst, da Charles har sagt til sin ledsagerske igennem livet og døden, at de ingenting har, og dog har de det hele: »- Her kan vi dø sammen, sagde Charles og så, at heller ikke hun var bange.

5. Peter Seeberg: Dinosaurusens sene eftermiddag, Viborg 1974, p.198. Herefter forkortet D. 
- Hvordan, sagde hun, hvordan kan vi dø, som vi skal. - Vi kan springe ud sammen, sagde han, jeg kan bære dig, og jeg kan springe, vi kan tage tæppet omkring os, så vi ikke efterlader noget. Måske bærer luften os, måske gør den ikke. Så er vi sammen. ${ }^{6}$ I udspringet folder det nye liv sig ud. Der bliver gjort en begyndelse, som imidlertid ligger indlejret $\mathrm{i}$ den intethed, hvor alt er uvist og der ikke er nogen vej tilbage. De sætter alle sejl til og efterlader intet. I denne yderste udsathed i mødet med elementerne frilægges menneskets grundvilkår, at døden og livet tilskikkes mennesket, som i sidste ende må lade det omgribende element, hvori det fødes og går under, briste eller bære. I Hyrder erfarede Leo det omgribende i form af årstiden. I det katastrofiske øjeblik, hvor han mister herredømmet over sin bil, forvandler det omgribende sig til det omsiggribende. Her falder Leo ud af sin daglige rytme, sin egentid, og indfældes i årets cyklus, der kigger frem af det sår, som Leo trækker efter sig.

\section{Åndedrætsbesvær}

Jeg vil nu runde de tidlige værker før Hyrder for at fremlæse et lignende tidsfænomen som i de senere værker; men vi vil se, at tiden ikke omfatter årstidernes hele kredsbevægelse, men menneskets pulsslag, åndedrottet. I Seebergs debutroman Bipersonerne kommer Sims fortvivlelse helt kort til udtryk i den følgende refleksion: "Han havde uforbederligt svært ved at leve i verden og uforbederligt svært ved at være sig selv. Man kunne måske ikke begge dele. $\ll^{7}$ Dette tekststed er skrevet i oktober 1953, og Seeberg har i det samme år arbejdet med novellen "Spionen", som første gang udkommer året efter, for siden hen at blive trykt som den første novelle i Eftersøgningen. At der er et tematisk fællesskab mellem Sim og spion-jeg'et, viser sig i den retorisk storslåede afslutning på »Spionen«:

»Men en dag står det evige, abstrakte spørgsmål med dets: hvad vil du? over for mig, og jeg må enten vælge lidt af hele verden, eller det hele af lidt af verden. Jeg må distrahere mig eller koncentrere mig - udånde eller indånde, spionere eller lade mig gribe. Ingen anden mulighed. $\|^{8}$

Slægtskabet imellem Sim og spion-jeg'et består i, at de begge forsøger at udgrunde deres jegs forhold til verden igennem disjunktionen. Det vil sige,

6. Peter Seeberg:Argumenter for benådning, Viborg 1976. Herefter forkortet $A$.

7. Peter Seeberg:Bipersonerne, Kbh. 1975 (org. 1956), p.107. Herefter forkortet $B$.

8. Peter Seeberg:Eftersøgningen, Kbh. 1973 (org.1962), p.18. 
at Sim tvivler på, at han både kan leve i verden og være sig selv, og at han derfor enten må gøre det ene eller det andet, hvilket spion-jeg'et absoluterer ved kun at anse den ene pol i modsætningsparret for at være en mulighed. At distrahere sig, udånde og spionere udgør den ene side af spionens modsætning og svarer til Sims »at leve i verden«, mens dét at koncentrere sig, indånde eller lade sig gribe udgør den anden side, der svarer til Sims »at være sig selv«. Sammen med Tom i Fugls føde er disse randeksistenser splittet imellem en udadgående bevægelse imod verden, og en indadgående bevægelse imod sig selv, og ingen af dem formår at formidle henover den kløft, der har åbnet sig i deres sind og i forhold til deres nærmeste omgivelser. De lider af åndedrætsbesvær, hvilket i Sims tilfælde viser sig, da han en nat er ved at opleve et gennembrud inde fra sit psykiske indelukke, og det er som om der er én, der lægger en hånd for hans mund ( $B$, p.167). Tom er ude af stand til at stå stille og få vejret, og er som følge heraf i konstant bevægelse på stedet. Og spion-jeg'et halser efter den gruppe på tretten cyklister, som han udspionerer, indtil han finder ud af, at for at være med skal han få cyklen til at rulle i en rytmisk, glidende bevægelse; men hvor tæt de alle tre end måtte være på at finde en udvej af deres indre labyrint, så falder de tilbage i deres evige refleksionskramper. I deres indædte kamp for at drive en mening ud af tingene stødes de tilbage i forfaldet. De forfalder til deres egen horisont, deres egen virkelighed, deres egen tid. Det er som om tiden trænger dem op i en krog, hvor de ikke længere kan få luft.

Sim er fanget i ledighedens tid, hvor der intet er at foretage sig, og hvor intet får afgørende betydning. Han gemmer sig i dunkelheden, hvor intet lys kan udstille hans lede og hans kedsomhed, men hvor "sindet«, som det hedder i Bipersonerne, »ja, det var som et lærred, hvor hændelserne faldt på som et skyggespil. Der hændte noget. Til ens store forundring. Man var ikke med i det.« (B, p.89) Det er den tomme tid, som falder én lang, uden at den får fylde, og som kan vende sig imod én, hvilket Tom erfarer, da han er alene med sig selv i sit hus:

»Han var alene, og han mærkede, at tingene var imod ham, huset var imod ham, stilheden var imod ham, når han sad og ingenting foretog sig. Skrækken lå som en ring omkring hans hjerte, han var ikke bange for noget, spøgelser troede han ikke på, og hvem skulle myrde ham, men der var en skræk, hvis time var ensomhedens, ledighedens, i den fik tomheden nåle og torne, og han måtte lide længe, til trætheden kom og dulmede« $(F f$, p.85).

Toms egen tid, nemlig tomhedens tid, er forfaldets og dødens tid, der ikke folder sig ud og giver plads, men krummer sig om den hjemsøgte, hvis hus, 
der burde være sikker grund, er blevet unheimlich, som tyskerne siger, når uhyggen gør sit indtog. Livets tid hverken strømmer eller gror, men Sims og Toms tid har nærmest slået en knude på sig selv, der slutter gennemstrømningen, og forårsager åndedrætsbesvær.

\section{Menneskets tilhørsforhold til tiden}

Hvordan bryde den onde cirkel, og komme ud på den anden side? I Seebergs forfatterskab er det ikke mennesket, der bryder fri; men der sker et ombrud. Friheden og tiden er ikke noget, der står til rådighed, men bryder ind udefra, udenfor jeg-husets vægge, og ryster mennesket i dets grundvold. Det var årets tid, der satte en stopper for Leo Grays fremdrift; den klamme, kolde, fugtige luft, der bredte sig i tågelandskaber over vejbanen uden at solen kunne komme igennem. En tid, der dog samtidig viste et sommerligt voksested, som mennesket måske langsomt kunne træde i forbindelse med ved lyttende at lægge hovedet ind til stammen. Jeg skal forsøge at vise hvorledes dét at lytte er den diskrete sans, hvormed de seebergske eksistenser har en mulighed for at forvinde deres kvaler, mens lukningen af hørelsen samtidig varsler undergangen.

Tom forsøger faktisk på et tidspunkt i Fugls føde at klamre sig til et træ, og opnå kontakt med en tilsyneladende uopnåelig naturlighed. (Ff, p.91) Denne mulighed åbner Seeberg imidlertid først i sit værk fra 1986, Varkfører Thomsens endelige hengivelse, hvor Thomsen forliger sig med et stort lindetræ:

»Han spurgte lindens ånd med begge arme knuget om træet og munden tæt til barken og derpå med øret presset som til en nedslidt høretelefon og hørte svar fra ånden, der langsomt steg ned i roden til vinterdvalen, til dybdestrøm og genskabelse af forårssaft. «"

Et næsten analogt tekststed findes i den fine trilogi om drengen, der søger et navn. I det første bind hedder det: »Han lagde øret til træet, og han hørte, at det klukkede derinde. Det var livssaften, sagde moderen, det var frøen, der fik den til at stige. I alle træer ville livssaften stige nu i de kommende dage. ${ }^{10}$ Som vi allerede er blevet opmærksomme på, får mennesket i Seebergs senere værker en mulighed for at træde i forbindelse med et større, kosmisk skæb-

9. Peter Seeberg:Varkfører Thomsens endelige hengivelse, Kbh. 1986, p.15.

10. Peter Seeberg: Uden et navn, Kbh. 1996, p.. 44. 
neforløb, hvis det evner at lytte til det omgivende steds indfældethed i årstidernes cyklus.

Tom mangler imidlertid evnen til at lytte, hvilket flere gange kontrastivt antydes igennem særlingen Hiffs, der har lært af musikken og som har en indre fast og føjelig, rytmisk struktur. Ligesom spion-jeg'et, der gemmer sig inde bag sin ansigtsmaske, orienterer Tom sig ved hjælp af synssansen, den majestætiske sans, der forsøger at erobre og overskue tingene, så de kommer under kontrol. I Seebergs univers underløbes ethvert forsøg på at vinde herredømmet imidlertid af tidens tilintetgørelse: For Tom får tiden torne, og spion-jeg'et udstødes af cykeltruppen, fordi han ikke er i stand til at høre til i den tidens fylde, som cyklisternes organiske åndedrætsbevægelse skaber. $A t$ høre til eller at tilhøre udtrykker det forhold, at mennesket er givet hen til en større omgribende sfære ligesom øret er givet hen til sine akustiske omgivelser. I modsætning til øjet, der på distance registrerer sit objekt. Novellen »Braget« fra Eftersøgningen illustrerer, hvorledes dét at lytte ikke kun er en aktiv handling, hvor mennesket sætter sig hen og lytter, men først og fremmest skal forstås som det tilhørsforhold, mennesket vedvarende befinder sig i til tiden. Også personerne i »Braget« forsøger som gode børn af den europæiske oplysningstradition at udgrunde braget ved hjælp af synssansen, men kommer til kort, da der ingenting er at se. Braget har slet ikke nogen identificerbar grund uden for mennesket selv, hvilket bliver klart, da beboerne i ejendommen styrter ud på trappen, da det lød som om den faldt ned. Beboerne er åbenbart ligesom Tom hjemsøgte af deres egen angst for, at deres udsatte bosted skal falde sammen. Menneskets angst for hvad, der måtte komme, er selve den grund, hvorudfra braget lyder.

\section{Årstiderne}

Mennesket er ikke i tiden ligesom det er i rummet, men det tilhører tiden tiden som bebor mennesket i angsten, i kedsomheden og i ledigheden. Jeg vil nu føre linjen fra Hyrder videre, så det bliver klart i hvilket omfang, Seeberg lader tiden brede sig ud fra de tidlige randeksistensers egentid til at omfatte årstiderne.

I 》Vinterens komme« fra Argumenter for benådning beskrives moderens indre tilstand som »en lavine, som hun er midt i, og tømmer fra norske fjeldhytter, som rager op over sneraset, og hende selv midt $\mathrm{i}$, ude af stand til at skrige.« $(A$, p.101) Vinteren har ikke blot lagt sig rundt omkring i landskabet, men "[D]et står op i armene på hende, det sidder i hendes mund, det er vokset som en fin hinde foran hendes øjne. Hun ser kun det grå, det gråhvide« $(A$, p.103). Det er først da hun hjælpeløs må overvære sin datters 
drukneulykke, at der sker et omslag i hendes sind: "Det begynder at blæse gennem hende, sne og solskin og skyer og vand bevæger sig op og ned gennem hende $[\ldots] \ll(A$, p.106). Elementerne raser i hende, og hun oplever sin egen tid som overgangstid - for at hente et ord fra Seebergs tekst, »Klima«, i Om fjorten dage. Årstiderne danner en organisk struktur, hvor de enkelte årstider griber ind i hinanden, hvilket vi så i Hyrder, hvor foråret og sommeren pulserede under den klamme bark i november. Og ligeledes her i »Vinterens komme«, hvor moderens lukkede tilhørsforhold åbner sig i det øjeblik der sker et omslag, og elementerne og årstiden, præcis den tid der i Seebergs senværk grunder selve den menneskelige eksistens, gennemstrømmer hende.

I »Klima« griber verdens fænomener ind i hinanden i et gensidigt vekselvirkningsforhold, der udjævner alle ekstreme forskelle. Både på overfladen og i dybet balancerer de klimatiske forandringer, idet en stigning afløses af et fald. Og i en vis forstand holder forfaldet allerede til i opstigningen, der på et tidspunkt når et højdepunkt, hvorfra det kun går nedad. Årstidernes skiften og temperaturens svingninger er kun udslag på en evigt foranderlig bevægelse, hvor »[A]lt er overgangstid «. ${ }^{11}$ Arets perioder melder sig ikke til bestemt fastlagte tidspunkter, men forskyder sig og underløber andre perioder. Således kan vinteren virke sommerlig, mens det sene forår endnu ikke har udvisket sporene fra vinteren. Klimaet fremviser tiden i dens kontinuerlige varen, som breder sig ud i alle retninger. Omslaget er en del af en større virkningsenhed, "altet«, der forbliver sig selv igennem alle omskiftelserne.

I Vinterens komme« var årstiderne også menneskets tid og en del af dets sjælelige oplevelsesapparat. I »Klima« er der ikke blot overgangstid i det omkringliggende landskab, men den sætter sig igennem i det indre, hvor håbløshedens tilstedeværelse binder håbet til grunden. Også i sjælen spilles dybet og overfladen ud imod hinanden, idet de, der har haft grund til at håbe, stødes tilbage i afgrunden af håbløsheden. Håbet vil ikke bryde igennem på grund af sin modsætningspol, som det står i et evigt udvekslingsforhold til. Tiden changerer imellem polerne i livets mange modsætningspar og bringer både håb og håbløshed, sundhed og sygdom, rigdom og fattigdom.

I Seebergs univers lader det sig ikke gøre kun at tage den ene side af modsætningen, men mennesket må leve med at være fastholdt i spændingen imellem de to poler, der altid allerede rummer hinanden i en virkningsenhed. Hvad der på overfladen tager sig ud som et sundhedstegn, kan allerede fra grunden af være blevet ramt af sygdom. Den vidstrakte horisontalitet er ikke uden dybde, men dybden er allerede en del af overfladen, så der er ikke noget at komme til bunds i, og mennesket vil søge forgæves, hvis det vil

11. Om fjorten dage, Viborg 1981, p.10 
grave sig ned igennem lagene. Det dobbeltvirkende forhold i tiden viser Marie i "Mariæ lovsang« fra Dinosaurusens sene eftermiddag at have et skarpt øje for: »- Er deres mand kommet på hospitalet? - Ja, sagde Marie, det blev for slemt. - Han så ellers så rask ud, sagde manden. - Ja, sagde hun, men det er længe siden det begyndte.« ( $D$, p.152.) Mennesket kan ikke tvinge tidens langvarige virkninger frem, men det må ligesom Marie vente på, at de med tiden sætter sig igennem. I denne tidsopfattelse ligger den seeberg'ske eksistensforståelse indfoldet, at mennesket må besinde sig på sin endelighed og elske sin skæbne. I verdens vidtstrakte horisontalitet, hvor året går på hæld og livsdagen bliver kortere, dér er mennesket undervejs.

\section{At leve i og med mørket}

Seebergs forfatterskab placerer sig i efterårsmånederne, ud på den sene dag, hvor skyggerne bliver lange og mørket vinder indpas. Vi så det i de tidlige værker, hvor randeksistenserne imidlertid ikke var forbundet med naturens cyklus, men var indesluttet i deres eget kredsløb og følte sig forfulgte af deres egne og civilisationens skygger. Efter afslutningen af novellen »Patienten« til Eftersøgningen skete der et skred i Seebergs egen tilværelse, der samtidig peger på overgangen fra forfatterskabets koncentration om den hermetiske og udvejsløse eksistens, der ikke kan få vejret, til at åbne sig imod hele det landskab, hvori mennesket er indfældet: »Det betød, at der nu var åbnet et vindue et eller andet sted, og at jeg nu kunne trække vejret. ${ }^{12}$ De tidlige eksistenser er usårlige på en måde, der grænser til det umenneskelige. Det gælder både de alt for menneskelige, Sim, Tom og spion-jeg'et, men også de overmenneskelige naturer, balteren og Hiffs, hvis jeghuse er så perfekt afsluttede, at deres handlinger og udsagn får lov til at stå uimodsagte. De to vismænd kan komme alle til hjælp, men ingen kan komme dem til hjælp, fordi de så at sige har indoptaget tilværelsens kontingens i deres kredsløb, og er blevet uimodtagelige for tidens tilintetgørelse. Denne hermetiske uberørthed sprænges med »Patienten«, og for alvor i Hyrder, hvor den menneskelige eksistens rives med af kræfter, der uforudsigeligt omvælter tilværelsen:

»Der måtte i sådanne tilfælde en overbevisende katastrofe til at bytte om på rollerne, mellem dem, der var kaldet til at hjælpe og dem, der skulle

12. Henk van der Liet (red.): Indfaldsvinkler - en forfattersamtale mellem Peter Seeberg og Poul Vad, Kbh. 1998, p. 83. 
hjælpes, skønt i verden som helhed ingen kunne afgøre hvem, der var hjælpeløs, og hvem der var hjælper« (H, pp.22-23).

I forlængelse af den katastrofe, der sårer Leo Gray for livet, finder vi igennem de senere værker en stribe af sårbare væsner, der lever med deres udsathed i omslagspunktet, faldet og - hvad jeg vil komme ind på her til sidst - mørket. I »Det sidste mørke« fra Rejsen til Ribe har Hansens igennem alle generationer indrettet sig i mørket, der efterhånden er forsvundet som en følge af den ekspanderende civilisations oplysningsbestræbelser. Den sidste Hansen har imidlertid ligesom sin far indrettet sig med det elementære mørke og fundet en stor glæde heri, hvorfor »lysmenneskene« må forekomme ham dekadente:

„Kunne blot mørket blive stående over hans plet, tænkte han tit, når han havde været et vend ude i natten: træerne i mørke, luften i mørke, jorden i mørke, bygningerne i mørke. Det kunne nok ikke lade sig gøre, sådan som folk var forfaldne til lys. «" ${ }^{13}$

Den fremskredne oplysning er et udtryk for forfald, og menneskene forfalder med lyset. Med udelukkelsen af de skyggefulde og hemmelighedsfulde sider ved tilværelsen, synes menneskeheden at gå mod stadig større klarhed, men dermed glemmes, ja lyset fortrænger tilværelsens grundlæggende vilkår, som angår menneskets egen eksistens: at mørket til sidst tager alt tilbage i sig. Også Leo Gray og dinosaurusen måtte sande, at deres egen endelighed rummede et yderste, mørkeste mørke, som efterlod et uhåndgribeligt spor i den dødes fysiognomi. Titlen »Det sidste mørke« spiller på dobbeltheden af, at den sidste Hansen repræsenterer det sidste mørke $i$ kulturen, men at selv den moderne civilisation vil blive underløbet af det sidste mørke $i$ eksistensen, som også Hansen til sidst indhentes af: „Han ville vel helst være død en mørk vinternat, men det blev en klar sommermorgen i stedet. Han faldt om med knugede hænder, som om han i det mindste dér ville holde mørket fast« $(R R$, p.90). I Seebergs værker ligger der et forsonende skær over døden i de tilfælde, hvor det levende til sidst hjemfalder til det, som det har elsket. Der ligger en sidste omfavnende gestus i Charles' frie fald imod vandet, der måske vil bære, og man kunne nævne tre andre tekster fra Rejsen til Ribe: Den agurkeglade hunds lighed med agurkens essens i dødsøjeblikket, Laust Gudmundssøns brev om at alting opstår af og går under i bly og den afdødes håndstilling i »Den anatomiske tegning«. Da Hansen ikke

13. Rejsen til Ribe, Viborg 1990, p.. 90 - min kursivering. Herefter forkortet RR. 
kan forlige sig med mørket i dødsøjeblikket, må han opsøge det på anden vis: I ensomhed tager han vare på det i de knugede hænders sidste taksigelse.

Der er imidlertid også dem, der ikke kan forlige sig med mørket og gå taknemmelige i døden, fordi de stadig må holde ud i angsten for, hvad der måtte komme. I titelnovellen »Halvdelen af natten« fra Seebergs sidste skønlitterære værk støder vi på en kvinde, der dybt inde i natten forbereder sig på at sove, for - som hun siger - det må hun forberede sig længe på. I sin seng ligger hun og lytter til beboerne i resten af ejendommen og hendes afdøde mand, som hun synes at kunne høre komme hjem; men der er også noget andet i boligen, når der intet er udenfor eller indeni én selv at lytte til, nemlig den tavshed, der er opvokset i mørket. ${ }^{14}$ Denne tavshed mærker hun ikke blot i boligen, men »jeg ligger tom i hovedet «, ${ }^{15}$ som hun siger. Iscenesættelsen minder om et studie i dødens indtræffen med hende i den horisontale stilling lyttende til trinene fra sin afdøde mand, mens mørket gennemtrænger hende. I denne nat er der ikke længere nogen afgrund imellem et indre, tomt og upersonligt mørke og et tilsvarende ydre. Der er blot en glidende overgang - som også i sproget forløber uafbrudt, næsten i eet åndedrag - imellem hendes egen indre dialog og dens ophør, der beskrives som en tilbagetogsbevægelse ud i natten:

"Tal nu lidt langsommere, der er ingen grund til at tale så hurtigt, det forsvinder alligevel, derind hvor det kom fra, bort i natten, sådan kørte statsbanerne ud fra Varde station med den røde bageste lygte til også den forsvandt. Jeg ser det for mig, det kan jeg se, jeg kan blive ved at se dette syn, lige hvor den røde lygte forsvinder, lige ved at forsvinde, så går jeg hjem, og min veninde Terese fra Ølgod vil snart være hjemme og blive hentet ved stationen« $(H d n$, p. 81).

Natten har lagt sig omkring hele hendes tilværelse i huset, hvor der ingen adskillelse er imellem jeghusets og jernbanevæsnets nat, og hun fortsætter søvnløst langs de skinner, som hun er kommet ad.

14. I disse overvejelser har jeg ladet mig inspirere af Merleau-Ponty, hvis refleksioner forekommer mig at kredse om samme intethedserfaring. "Hvorfra kommer stemmen?«, spørger Merleau-Ponty, og svarer selv: fra »tavsheden« og »tomheden« inden i os, fra et sprog, der er "opvokset i mørket«. Se den danske oversættelse i Ole Fogh Kirkebys Verden, ord og tanke, pp..124-25.

15. Halvdelen af natten, Kbh. 1997, p.78. (Herefter forkortet Hdn.) 